\title{
In silico investigation of antioxidant interaction and effect of probiotic fermentation on antioxidant profiling of pearl millet-based rabadi beverage
}

Prakash Yadav

Department of Nutrition Biology, Central University of Haryana, Jant-Pali, Mahendergarh -123031 (Haryana), India

\section{Adarsh Kumar Shukla}

Department of Nutrition Biology, Central University of Haryana, Jant-Pali, Mahendergarh -123031 (Haryana), India

\section{Tejpal Dhewa}

Department of Nutrition Biology, Central University of Haryana, Jant-Pali, Mahendergarh -123031 (Haryana), India

Ashwani Kumar*

Department of Nutrition Biology, Central University of Haryana, Jant-Pali, Mahendergarh -123031 (Haryana), India

${ }^{*}$ Corresponding author. Email: ashwanindri@gmail.com

\section{How to Cite}

Yadav, P. et al. (2021). In silico investigation of antioxidant interaction and effect of probiotic fermentation on antioxidant profiling of pearl millet-based rabadi beverage. Journal of Applied and Natural Science, 13(4), 1531 - 1544. https:// doi.org/10.31018/jans.v13i4.3154

\begin{abstract}
Pearl millet-based food products can be used for weight control and minimize the possibility of chronic diseases. They have protein, minerals, fat, phenolic compounds, and a diminutive glycemic index. Moreover, Probiotic fermentation can bring specific additional benefits in addition to nutritional improvements. In silico analysis of the chemical-protein interaction of tannic acid and ascorbic acid of pearl millet was undertaken. Further, the role of fortification of rabadi beverage by probiotic culture was also assessed in this study at different temperatures $\left(35,42\right.$, and $\left.45^{\circ} \mathrm{C}\right)$ of fermentation. In silico study has predicted the association of both tannic acid and ascorbic acid with the various human proteins responsible for the growth and development of the human immune system. In all used probiotic (Lactobacillus rhamnosus, Lactobacillus sp. and Streptococcus faecalis), L. rhamnosus fortified rabadi beverage at continuous increasing temperature $\left(35,42,45^{\circ} \mathrm{C}\right)$ of non-autoclaved batch showed high content of TAC $\left(36.83 \pm 5.41 \mu \mathrm{g} \mathrm{mL}{ }^{-1}\right)$, TPC $\left(46.1 \pm 8.28 \mu \mathrm{g} \mathrm{mL}^{-1}\right)$ and TFC $\left(29.91 \pm 7.73 \mu \mathrm{g} \mathrm{mL}^{-1}\right)$; while decrease in tannins content $\left(14.84 \pm 4.64 \mu \mathrm{g} \mathrm{mL}^{-1}\right)$ as compared to control [TAC $\left(29.32 \pm 3.17 \mu \mathrm{g} \mathrm{mL}^{-1}\right)$, TPC $\left(25.53 \pm 5.75 \mu \mathrm{g} \mathrm{mL}^{-1}\right)$, TFC $(21.91 \pm 5.95 \mu \mathrm{g}$ $\left.\mathrm{mL}^{-1}\right)$, and Tannins $\left.\left(20.74 \pm 3.43 \mu \mathrm{g} \mathrm{mL}^{-1}\right)\right]$. L. rhamnosus fortified rabadi beverage of non-autoclaved batch showed better results than Lactobacillus $s p$. and $S$. faecalis fortified rabadi beverage of both batches (autoclaved and non-autoclaved); which in turn expressed the enhanced therapeutic activity of probiotic fortified rabadi beverage.
\end{abstract}

Keywords: Antioxidant profiling, In-silico, Pearl millet, Probiotic fermentation, Total antioxidant capacity

\section{INTRODUCTION}

Millet is generally used as a source of nutrients and dietary energy in African and Asian subcontinents (Krishnan and Meera, 2018; Rani et al., 2018). Pearl millet is protein-rich (Agrawal et al., 2016), has high lipid content, presence of phenols, flavonoids, carotenoids have relevance for the antioxidant activity that point outs the interest of pearl millets towards human health benefits (Falcinelli et al., 2018). Therefore, all age groups have consumed traditional fermented pearl millet grains in breakfast or as a refreshment food in all regions of Nigeria and sub-Saharan Africa. Pearl millet grain has been recognized to possess vital nutritive values, which include proteins $(10.96 \mathrm{~g} / 100 \mathrm{~g})$, iron $(6.42 \mathrm{mg} / 100 \mathrm{~g})$, calcium $(27.35 \mathrm{mg} / 100 \mathrm{~g})$, carbohydrates $(61.78 \mathrm{~g} / 100 \mathrm{~g})$, as well as numerous phenolic compounds (Longvah et al., 2017). These nutrients contribute to the antioxidant and healthful benefits of the pearl millet (Akinola et al., 2017; Banwo et al., 2021a; Obadina et al., 2017). Nutritional values, functional properties, and enhancement of health benefits 
of grain substrates have been improved with controlled fermentation using selected strain (Menezes et al., 2018; Okoroafor et al., 2019; Yepez et al., 2019; Sidari et al., 2020). Several phytochemical compounds like tannins, phenolic acids, and flavonoids have high antioxidant properties in fermented food products and have been highly suggested by dietetics in daily consumption (Chandrasekara and Shahidi, 2012; Olojede et al., 2020). Potent antioxidant eliminates the free radicals from the human body that prevents the cardio-cerebral syndrome, deferring decrepitude, and work as an anticancer (Noratto et al., 2009), bacteriostatic ( $\mathrm{Ng}$ et al., 2019), liver-protecting agents (Callcott et al., 2018), as an anti-infectent (Pěsic et al., 2019), cholesterolreducing agents (Liu et al., 2018), immunity developer agents (Cuevas et al., 2013). They play a vital role in preventing various disorders like type 2 diabetes (Xiao et al., 2013; Vitale et al., 2017). The previous study has been stated that probiotics-based foods and drinks have conferred the enhancement of host health when entered the live microorganism in sufficient quantity (Hill et al., 2014). Probiotics have inhibited the treatment and prevention of various diseases, and since ancient times, probiotics have been used as a bio-therapeutics agent (Alard et al., 2018; Hager and Ghannoum, 2017; Kerrman and Deshpande, 2014; Reid, 2017).

Rabadi beverage is widely used as a fermented beverage for human consumption. Traditionally, it is prepared with the help of pearl millet (Pennisetum typhoideum (L.) flour's, fermented with sour buttermilk in various concentrations. The study was undertaken to evaluate the association of the tannic acid and ascorbic acid with the various human protein as well as the functional therapeutic potentials of Lactobacillus rhamnosus, Lactobacillus sp., and Streptococcus faecalis fortified pearl millet-based rabadi beverage through controlled fermentation.

\section{MATERIALS AND METHODS}

\section{Materials}

Pearl millet and buttermilk (mother dairy) for the standard inoculum were purchased from Mahendragarh, Haryana's local market. L. rhamnosus ATCC was procured from Himedia Laboratories Pvt Ltd. Lactobacillus sp. and $S$. faecalis were generously gifted by Dr. Gunjan Goel, Central University of Haryana Mahendragarh, Haryana, India.

\section{Methodology \\ Network analysis}

Interaction between proteins and chemical molecules is beneficial for the understanding of cellular as well as molecular functions of the compounds. Online network database STITCH (Search Tool for Interactions of Chemicals) was used for the chemical-protein interac- tion of tannic acid and ascorbic acid of pearl millet. STITCH (http://stitch.embl.de/) database is widely used in the interaction of metabolic pathways, 3-dimensional structures of molecules, experiments related to binding between protein and chemicals, and DTIs (drug-target interactions).

\section{Milling}

Pearl millet grains were collected and washed out to remove external matter. Subsequently, the grains were dried in a hot air oven at $70^{\circ} \mathrm{C}$ for $7 \mathrm{~h}$ (Ogodo et al., 2018). The dried grains were ground into flour with a grinder. The whole flour was filtered through a mesh screen and put in storage such as a desiccator.

\section{Preparation of slurry for fermentation}

The pearl millet flour is assorted with distilled water and buttermilk to form a slurry for fermentation (nonautoclaved batch). However, it was subsequently autoclaved to obtain another batch (autoclaved). The slurry so obtained was cooled down to room temperature.

\section{Inoculum preparation}

L. rhamnosus, Lactobacillus sp., and S. faecalis cultures were activated by inoculating in De Man, Rogosa, and Sharpe agar (MRS) broth and subsequently put on incubation for a period of $48 \mathrm{~h}$ at $37^{\circ} \mathrm{C}$. To achieve significant growth of bacterial population, sub-culturing was also carried out. The cells of the activated cultures were pelleted by centrifugation at $2500 \mathrm{rpm}$ for $5 \mathrm{~min}$.

\section{Fermentation}

The traditional practice of rabadi beverage fermentation is carried out in summer at room temperature, generally in the range of 40 to $50{ }^{\circ} \mathrm{C}$ in the northwest region. Therefore, the temperature for the fermentation process opted around this range. The fermentation process was performed for $12 \mathrm{~h}$ individually at different temperatures $35{ }^{\circ} \mathrm{C}, 42{ }^{\circ} \mathrm{C}, 45^{\circ} \mathrm{C}$. However, another setup was carried out at continuously increasing temperatures at $35^{\circ} \mathrm{C}, 42{ }^{\circ} \mathrm{C}$, and $45^{\circ} \mathrm{C}$ with an interval of $4 \mathrm{hrs}$ at each temperature. The probiotic cultures were mixed at room temperature, and subsequently, fermentation was additionally performed at $37^{\circ} \mathrm{C}$ for $24 \mathrm{~h}$. Before and after probiotic fermentation, the product was stored at $4{ }^{\circ} \mathrm{C}$ for further characterization.

\section{Preparation of methanolic extracts of pearl millet}

The methanolic extraction of the rabadi beverage sample was taken as per the given method of Zuo et al. (2002). Crush the air-dried rabadi beverage sample (5 g) and filter it through a $1 \mathrm{~mm}$ sieve. The methanolic extract was collected by adding $25 \mathrm{ml}$ of $80 \%$ methanol and stirred with an electric stirrer at ambient temperature for $3 \mathrm{~h}$. The flask contents were extracted two times with $80 \%$ methanol $(20 \mathrm{~mL})$, including $0.15 \%$ hy- 
drochloric acid under identical conditions. The methanolic extract was filtered through Whatman No. 42 filter paper $(125 \mathrm{~mm})$ or $0.45 \mu \mathrm{m}$ nylon membrane filter paper. Reduced the pressure to dry the extract at $45^{\circ} \mathrm{C}$ on a rotating evaporator and stored in a $-18{ }^{\circ} \mathrm{C}$ freezer until used for the additional characterization.

\section{Determination of total antioxidant capacity}

The TAC (total antioxidant capacity) was measured through the phosphomolybdenum procedure which has been stated in Prieto et al. (1999). Ascorbic acid (1 mg $\mathrm{mL}^{-1}$ ) was used as a standard. $1 \mathrm{~mL}$ of freshly prepared transfection suspension ( $0.6 \mathrm{M}$ sulfuric acid $\left(\mathrm{H}_{2} \mathrm{SO}_{4}\right)$, $28 \mathrm{M}$ sodium phosphate $\left(\mathrm{Na}_{3} \mathrm{PO}_{4}\right), 4 \mathrm{mM}$ ammonium molybdate mixture $\left[\left(\mathrm{NH}_{4}\right)_{2} \mathrm{MoO}_{4}\right]$ was added to $1 \mathrm{~mL}$ of rabadi beverage sample extract and $1 \mathrm{~mL}$ of various ascorbic acid concentration (10-50 $\left.\mu \mathrm{g} \mathrm{mL}^{-1}\right)$. Incubated the mixture for $90 \mathrm{~min}$ at $95{ }^{\circ} \mathrm{C}$ and cooled down at ambient temperature. Absorbance at $695 \mathrm{~nm}$ was measured with respect to a blank (same reaction mixture without rabadi beverage sample extract). The rabadi beverage sample was expressed in ascorbic acid equivalent per gram of extract. TAC (Total antioxidant capacity) test was used to measure the antioxidant capacity of all probiotic fortified batches.

\section{Determination of total phenols}

The phenols content of rabadi beverage samples was analyzed by Folin-Ciocaltu colorimetric technique of Singleton and Rossi (1965) with some modifications, using gallic acid $\left(1 \mathrm{mg} \mathrm{mL}^{-1}\right)$ as a standard. Different concentrations $(20-100 \mu \mathrm{g} \mathrm{mL}-1)$ of the standard were taken in a test tube and made up to $6 \mathrm{~mL}$ with distilled water for the standard curve. After adding $0.25 \mathrm{~mL}$ of Folin-Ciocaltu reagent, the mixture was incubated for 3 min at $25{ }^{\circ} \mathrm{C}$. $1 \mathrm{~mL}$ of saturated sodium carbonate $\left(\mathrm{Na}_{2} \mathrm{CO}_{3}\right)$ and $1 \mathrm{~mL}$ of distilled water were added to this mixture. Further, kept the mixture in the dark for incubation for $1 \mathrm{~h}$ at $25^{\circ} \mathrm{C}$. The resulting blue colour absorption was measured at $720 \mathrm{~nm}$ against white (equivalent reaction mixture without rabadi beverage sample extract). The same procedure was used to analyze rabadi beverage samples, except that gallic acid was replaced with $1 \mathrm{~mL}$ of rabadi beverage sample extract. The results were expressed as gallic acid equivalents ( $\mu$ mol gallic acid equivalents per gm of methanolic extract weight).

\section{Determination of total flavonoids}

The flavonoids content of rabadi beverage samples was measured by Chang et al. (2002) using quercetin $\left(1 \mathrm{mg} \mathrm{mL}^{-1}\right)$ as standard. A sample of $1.0 \mathrm{~mL}$ of rabadi beverage extract and several concentrations of the standard (20-100 $\left.\mathrm{g} \mathrm{mL}^{-1}\right)$ was taken in a test tube, and a volume of up to $5.0 \mathrm{~mL}$ was prepared using distilled water. $0.3 \mathrm{ml}$ of sodium nitrite solution $\left(\mathrm{NaNO}_{2}\right)(5 \%$, w/ v) and $0.3 \mathrm{ml}$ of aluminum chloride solution $\left(\mathrm{AlCl}_{3}\right)$
$(10 \%, w / v)$ added in the mixture. The contents were mixed and kept for 6 min before adding $2 \mathrm{~mL}$ of sodium hydroxide solution $(\mathrm{NaOH})\left(1.0 \mathrm{~mol} \mathrm{~L}^{-1}\right)$ and finally to a volume of $10 \mathrm{~mL}$. After the vortex, the absorbance of the solution was analyzed with respect to the blank (the identical reaction mixture without the methanolic extract of rabadi beverage) at $510 \mathrm{~nm}$. The same procedure was used to analyze the rabadi beverage samples, except to replace quercetin with $1 \mathrm{~mL}$ of rabadi beverage sample extract. Total flavonoids were equal to quercetin, which was calculated from the standard curve.

\section{Determination of tannins}

The tannins contents were determined according to the procedure described by Nwinuka et al. (2005). Tannic acid $\left(1 \mathrm{mg} \mathrm{mL}^{-1}\right)$ was taken as a standard for this test. The rabadi beverage sample extract and various concentrations of the standard $\left(20-100 \mu \mathrm{g} \mathrm{mL}^{-1}\right)$ were stirred with $0.5 \mathrm{~mL}$ of Folin - Ciocaltu reagent and 1.0 $\mathrm{mL}$ of $\mathrm{NaCO}_{3}$ solution $(0.5 \%, \mathrm{w} / \mathrm{v})$. Total volume was made up to $5.0 \mathrm{~mL}$. The absorbance of the samples was estimated at $755 \mathrm{~nm}$ against a blank (the same reaction mixture without rabadi beverage sample extract). The amount of tannin was analyzed through the standard curve of tannic acid.

\section{Statistical analysis}

All the experiments performed in the study were done in triplicates, and the statistical analysis was conducted using an ANOVA with a single factor test to determine the level of significance as per the method of Howell (2012).

\section{RESULTS AND DISCUSSION}

\section{Chemical-protein network}

The edges of chemical-protein interactions are specific and valuable, i.e., proteins together contribute to a shared function; it does not mean that they are physically bonded to each other. The edge confidence score determines the relevance of the protein chemical interaction if the score is 0.150 weak interaction (not significant), the score is 0.400 mean interaction (least significant), the score is 0.700 high interaction (the most significant), and the score is 0.900 highest interaction (strong interaction) between chemical and protein.

\section{Protein- chemical network analysis of tannic acid}

Protein-chemical network of tannic acid predicted nine human proteins associated with the tannic acid and the same is shown in Fig. 1. Some important characteristics were obtained through this network analysis viz. number of nodes: 9 , number of edges: 3 , average node degree: 0.66 , the coefficient of clusters: 1 , expected number of edges: 10, and protein-protein interaction 


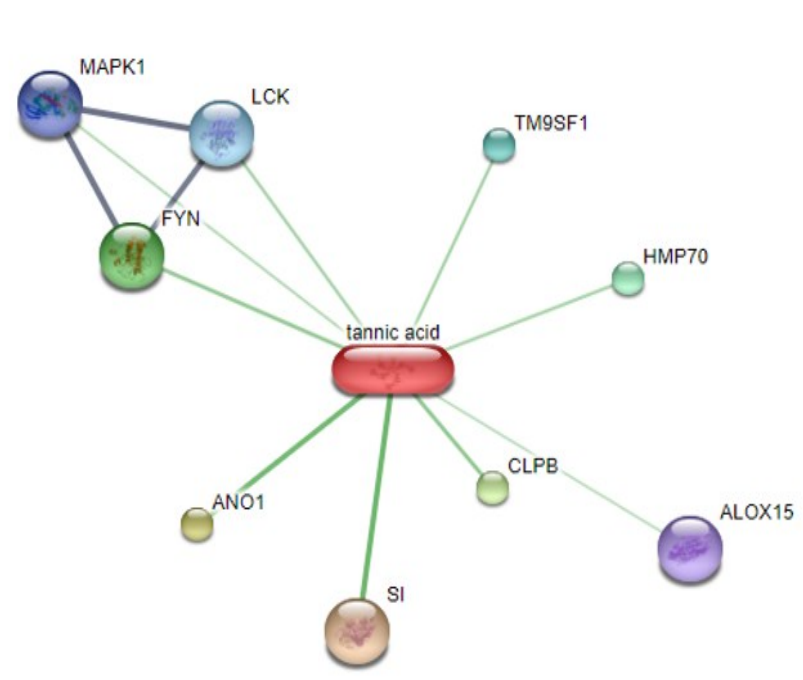

Fig. 1. Network of tannic acid interaction with human protein by STITCH database

enrichment p-value: 0.998 .

\section{Predicted functional partners of tannic acid}

Chemical-protein association is an important investigation to understand the effects of chemical moieties in human health. There were nine human proteins $\mathrm{SI}$, ANOI, CLPB, FYN, HMP70, TM9SF1, LCK, MAPK1, and ALOX15, directly associated with tannic acid. Table 1 shows the predicted protein partners with names and their functional activity. The ultimate goal of this Insilico work is to find the impact of tannic acid in human nutrition.

\section{Pathways analysis of tannic acid}

Kyoto encyclopedia of Gene and Genome (source: http://stitch.embl.de/.) is the database on biological systems used to analyze high-level molecular function and utilities. The STITCH Network database, based on chemical and protein association, showed that tannic acid interacts with the human protein in the default mode of STITCH database. Through the pathways analysis of tannic acid, many specific physiological functions were found responsible for osteoclast differentiation, NK (natural killer) cell facilitated cytotoxicity, $\mathrm{T}$ cell receptor signaling pathway, prion diseases, adherens junction, Fc epsilon RI signalling pathway, cholinergic synapse, serotonergic synapse, axon guidance and platelet activation. A detailed description of the same has been mentioned in Table 2 .

\section{Network analysis of ascorbic acid}

This protein-chemical network analysis found the ten human proteins that are associated with the ascorbic acid, as shown in Fig. 2. Some essential characteristics of network analysis were obtained for the ascorbic acid, i.e. number of nodes: 10 , number of edges: 0 , the

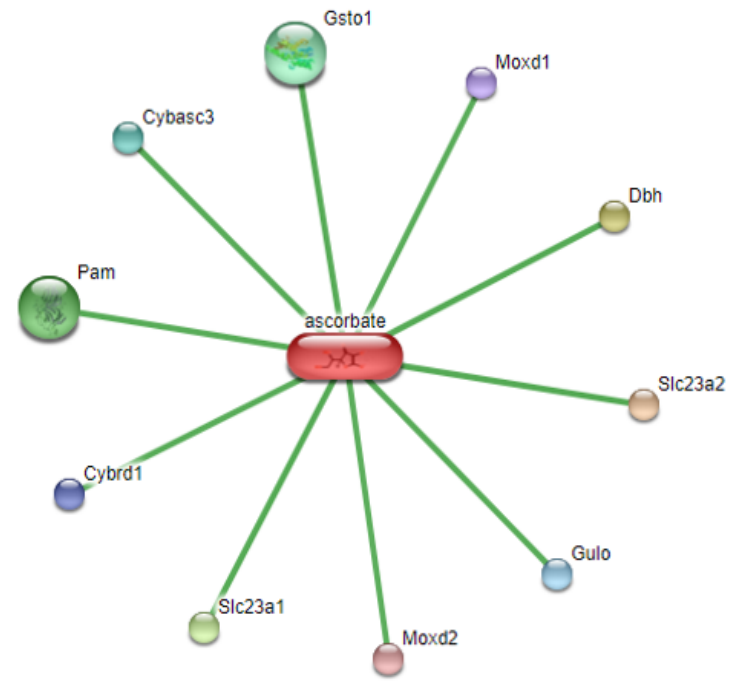

Fig. 2. Network of ascorbic acid interaction with human protein by STITCH database

average degree of node: 0 , the coefficient of clusters: 1, expected number of edges: 10, and protein-protein interaction enrichment $p$-value: 1 .

\section{Predicted functional partners of ascorbic acid}

STITCH database predicted the ten human proteins viz. Slc23a2, Dbh, Slc23a1, Pam, Gsto1, Cybase3, Gulo, Cybrd1, Moxd1, and Moxd2 are directly interacting with ascorbic acid. Table 3 shows the description and length of the human protein associated with ascorbic acid.

\section{Pathway analysis of ascorbic acid}

STITCH network analysis has predicted pathways of associated protein with the help of KEGG based on chemical and protein association. The predicted gene ontology (Molecular function, Biological process and Cellular components) of associated proteins, through the KEGG pathways, were 1) Molecular function: Lascorbate: sodium symporter activity, oxidoreductase activity, sodium-dependent L-ascorbate transmembrane transporter activity, L-ascorbic acid-binding, copper ion binding, 2) Biological process: L-ascorbic acid metabolic process, transepithelial L-ascorbic acid transport, oxidation-reduction process, small molecule metabolic process, response to transition metal nanoparticle, carboxylic acid metabolic process, single-organism metabolic process and 3) Cellular component: basal plasma membrane, an integral component of membrane, cell projection, basal part of the cell, whole membrane, apical part of the cell, transport vesicle membrane, secretory granule membrane, organelle membrane. Furthermore, details are given in Table 4.

\section{Optimization of the fermentation process}

The autoclaved batches contain a sterilized mixture of pearl millet-water-buttermilk suspensions to avoid any 
Yadav, P. et al. / J. Appl. \& Nat. Sci. 13(4), 1531 - 1544 (2021)

Table 1. Depicting the symbol of protein, the sequence length of the protein, description of protein, and a score of the node probability based on the experimental work in STITCH database for the tannic acid.

\begin{tabular}{|c|c|c|c|}
\hline Symbol & $\begin{array}{l}\text { Length } \\
\text { in aa }\end{array}$ & Description & Score \\
\hline SI & 1827 & $\begin{array}{l}\text { Sucrase-isomaltase (alpha-glucosidase) } \\
\text { Plays an important role in the final stage of carbohydrate digestion, and iso-maltase } \\
\text { activity is specific for alpha-1,4- and alpha-1,6-oligosaccharides. }\end{array}$ & 0.846 \\
\hline ANO1 & 986 & $\begin{array}{l}\text { Anoctamin 1, calcium-activated chloride channel } \\
\text { Calcium-activated chloride channel (CaCC) which plays a vital role in trans- } \\
\text { epithelial anion transport and smooth muscle contraction. } \\
\text { Acts as a major contributor to basal and stimulated chloride conductance in airway } \\
\text { epithelial cells and play a vital role in tracheal cartilage development. }\end{array}$ & 0.816 \\
\hline CLPB & 707 & $\begin{array}{l}\text { ClpB caseinolytic peptidase B homolog }(E . \text { coli) } \\
\text { May function as a regulatory ATPase and be related to the secretion/protein traf- } \\
\text { ficking process. }\end{array}$ & 0.627 \\
\hline FYN & 537 & $\begin{array}{l}\text { FYN oncogene related to SRC, FGR, YES } \\
\text { Non-receptor tyrosine-protein kinase plays a role in many biological processes, } \\
\text { including cell growth and survival regulation, cell adhesion, integrin-mediated sig- } \\
\text { naling, cytoskeletal remodeling, cell motility, immune response, and axon guidance. } \\
\text { It is involved in the regulation of cell adhesion and motility. }\end{array}$ & 0.612 \\
\hline HMP70 & 815 & $\begin{array}{l}\text { Transmembrane } 9 \text { superfamily member } 1 \\
\text { Plays an essential role in autophagy }\end{array}$ & 0.510 \\
\hline TM9SF1 & 606 & $\begin{array}{l}\text { Transmembrane } 9 \text { superfamily member } 1 \\
\text { Plays an essential role in autophagy. }\end{array}$ & 0.510 \\
\hline LCK & 509 & Lymphocyte-specific protein tyrosine kinase. & 0.507 \\
\hline MAPK1 & 360 & $\begin{array}{l}\text { Mitogen-activated protein kinase } 1 \\
\text { Serine/threonine kinase acts as an essential component of the MAP kinase signal } \\
\text { transduction pathway. } \\
\text { It participates in a signaling cascade initiated by activated KIT and KITLG/SCF. } \\
\text { Depending on the cellular context, the MAPK/ERK cascade mediates diverse bio- } \\
\text { logical functions such as cell growth, adhesion, survival, and differentiation through } \\
\text { the regulation of transcription, translation, cytoskeletal rearrangements. }\end{array}$ & 0.434 \\
\hline ALOX15 & 662 & $\begin{array}{l}\text { Arachidonate } 15 \text {-lipoxygenase } \\
\text { Converts arachidonic acid to } 15 \mathrm{~S} \text { - hydro peroxy-eicosatetraenoic acid. } \\
\text { It also acts on C-12 of arachidonate as well as on linoleic acid. }\end{array}$ & 0.405 \\
\hline
\end{tabular}

outsourced contamination. Autoclaving is reported to increase the digestibility of the autoclaved ingredient during fermentation. The autoclaved ingredient was potentially improved by different types of fermentation, i.e. natural and controlled fermentation (Sharma and Kapoor, 1996). The probiotic fortified rabadi beverage of both the batches (autoclaved and non-autoclaved) was analyzed for the antioxidant characterization.

\section{Total antioxidant capacity (TAC)}

The antioxidant contents having antioxidant potential are secondary metabolites of plants and are related to reducing the risk of chronic diseases related to oxidative stress.

As depicted in Fig. 3 and Table 5, L. rhamnosus fortified rabadi beverage at continuous increasing temperature $\left(35,42,45^{\circ} \mathrm{C}\right)$ of non-autoclaved batch showed maximum content of TAC $\left(36.83 \pm 5.41 \mu \mathrm{g} \mathrm{ml}^{-1}\right)$ as compared to other batches of probiotic fortified rabadi beverage as well as control fermented at various temperatures as mentioned in the methodology. Similarly, Ogunremi et al. (2015) showed the increased antioxidant potential of the grain-based beverage after fermentation with Pichia kudriavzevii OG32. The same fact has also been shown by Qian et al. (2012), who reported an enhancement in the antioxidant potential of Pavlova lutheri (microalgae) after fermentation by Hansenula polymorpha (Pichia angusta).

\section{Total phenols, total flavonoid, and total tannins contents}

Taylor and Duodu (2015) stated that phenolic compounds are considered as antinutrients because they are complex with proteins and other nutrients, thus pre- 


\begin{tabular}{|c|c|c|c|c|c|c|c|c|c|c|c|c|c|c|c|}
\hline 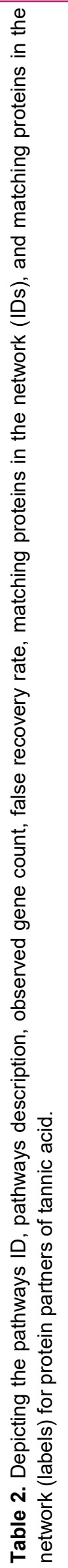 & 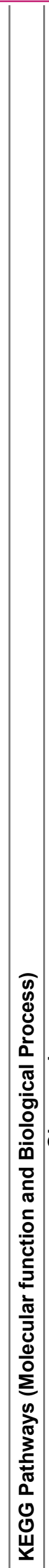 & 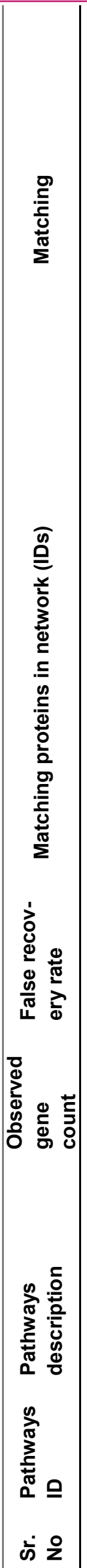 & 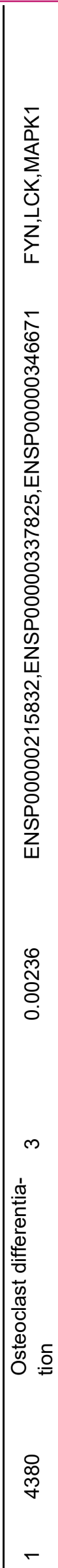 & 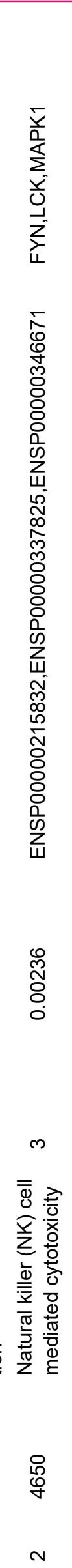 & 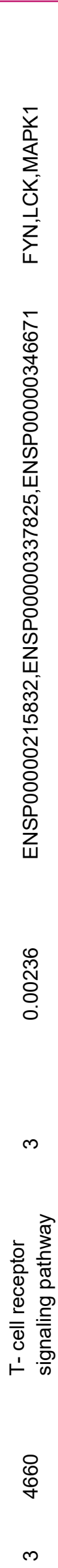 & 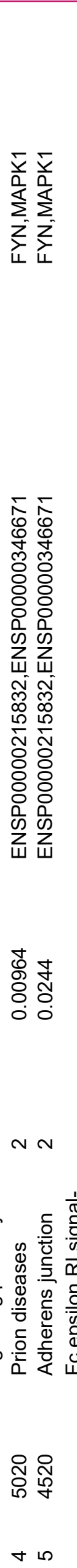 & 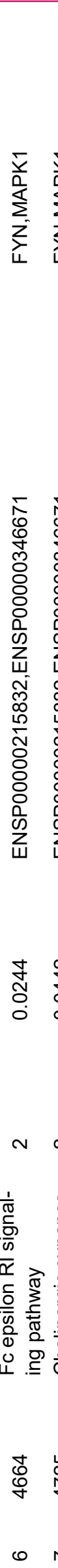 & 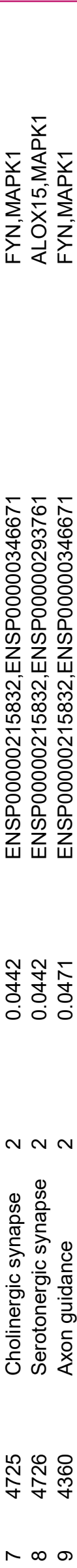 & 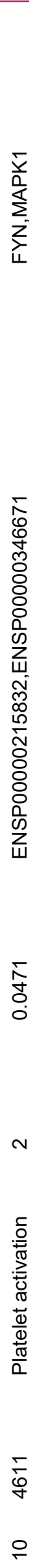 & & 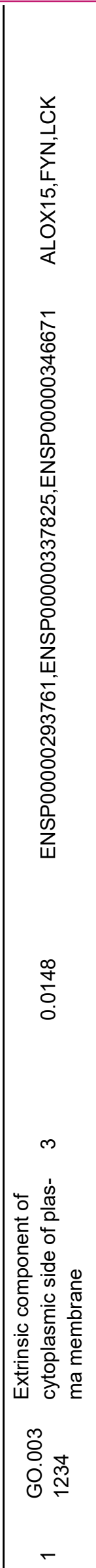 & 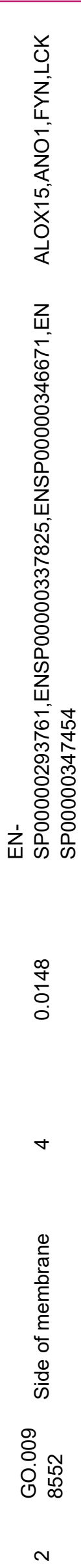 & 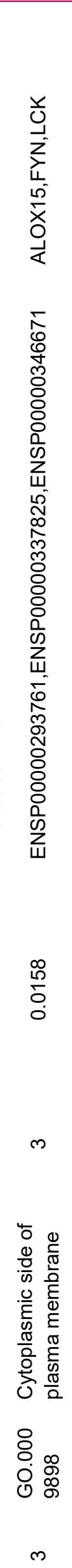 & 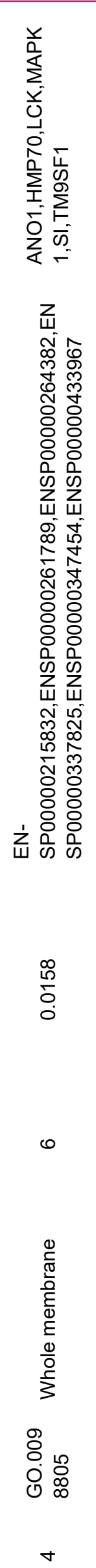 & 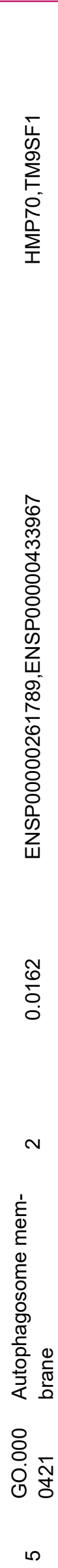 \\
\hline
\end{tabular}




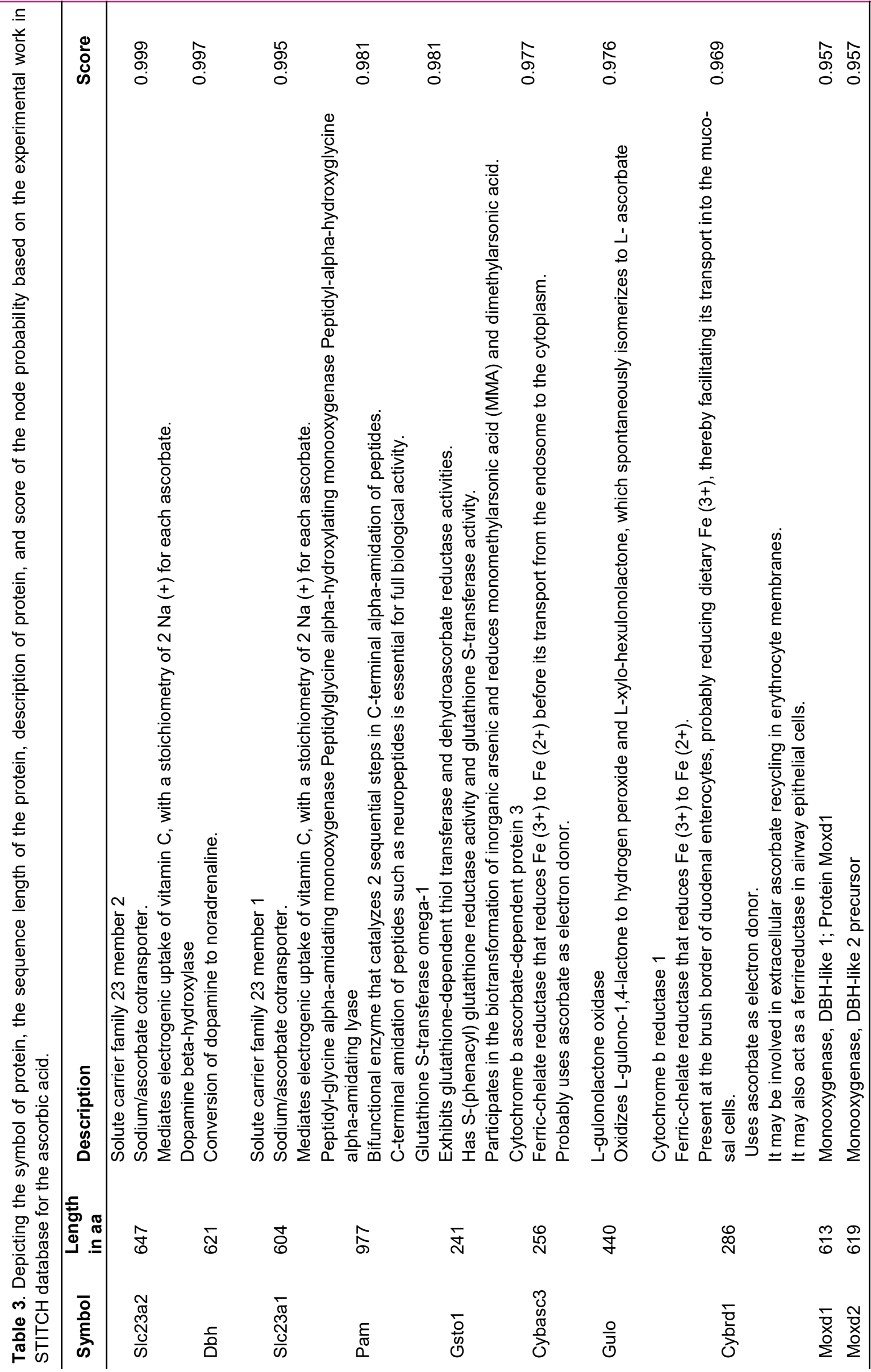


Yadav, P. et al. / J. Appl. \& Nat. Sci. 13(4), 1531 - 1544 (2021)

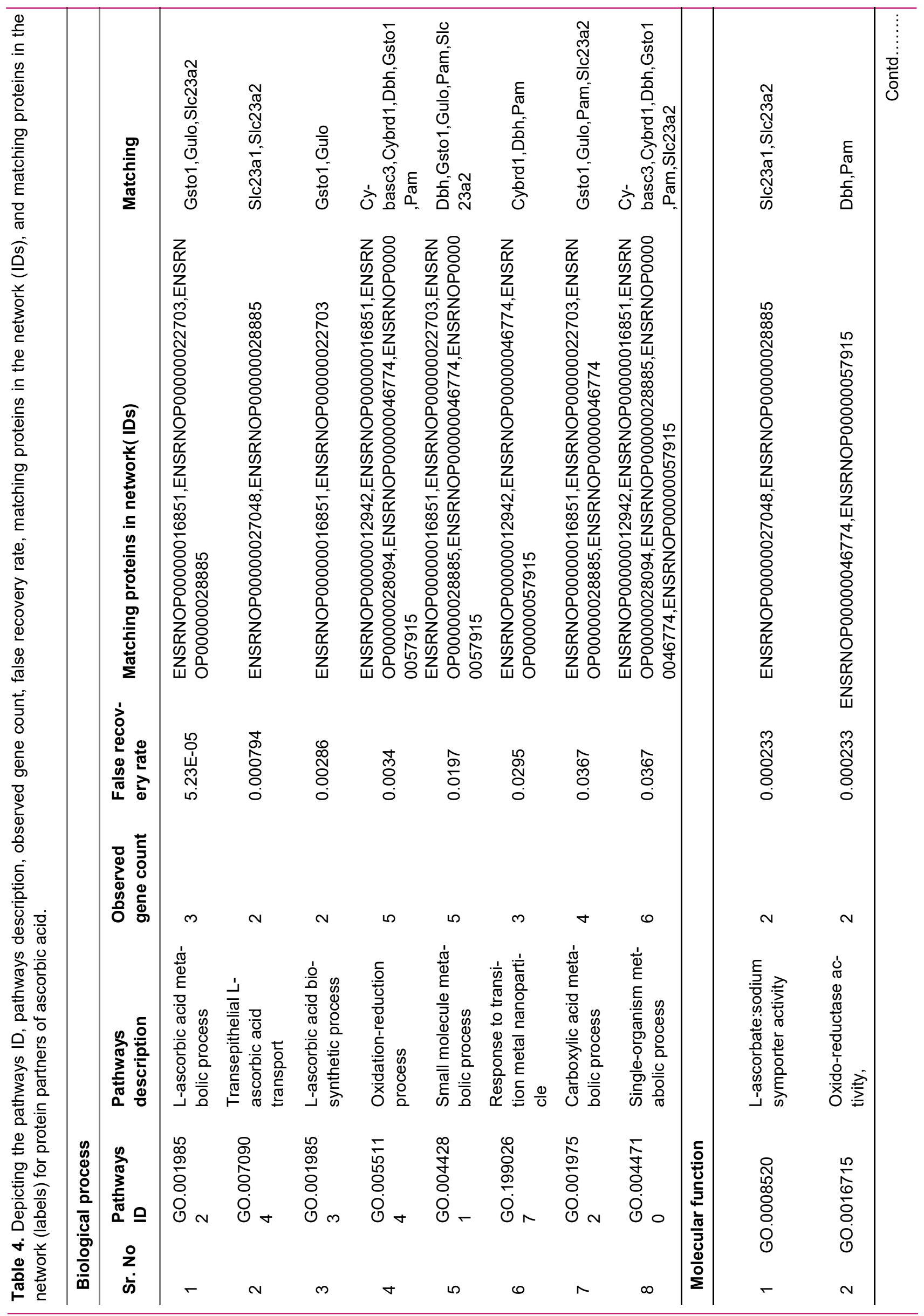




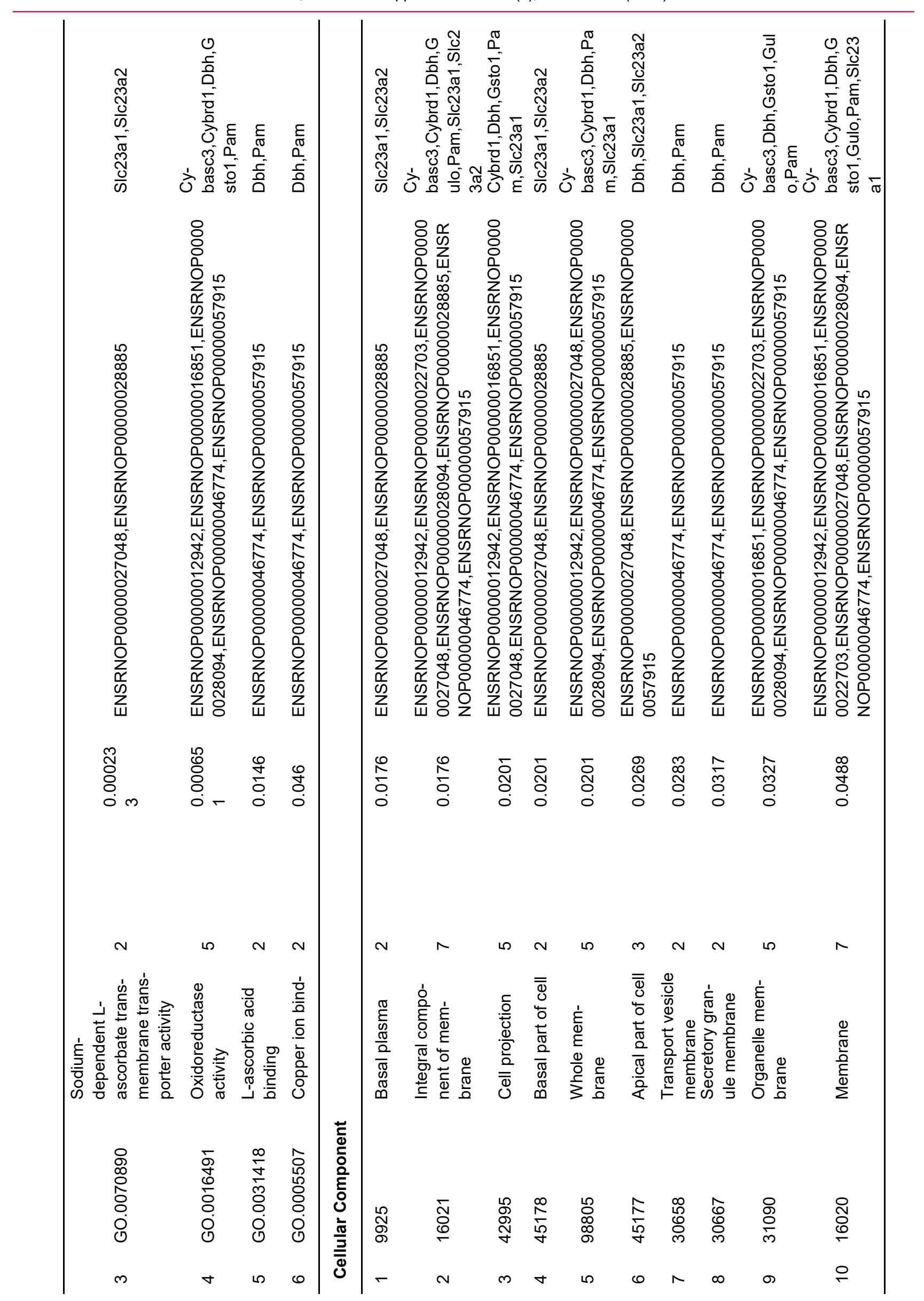



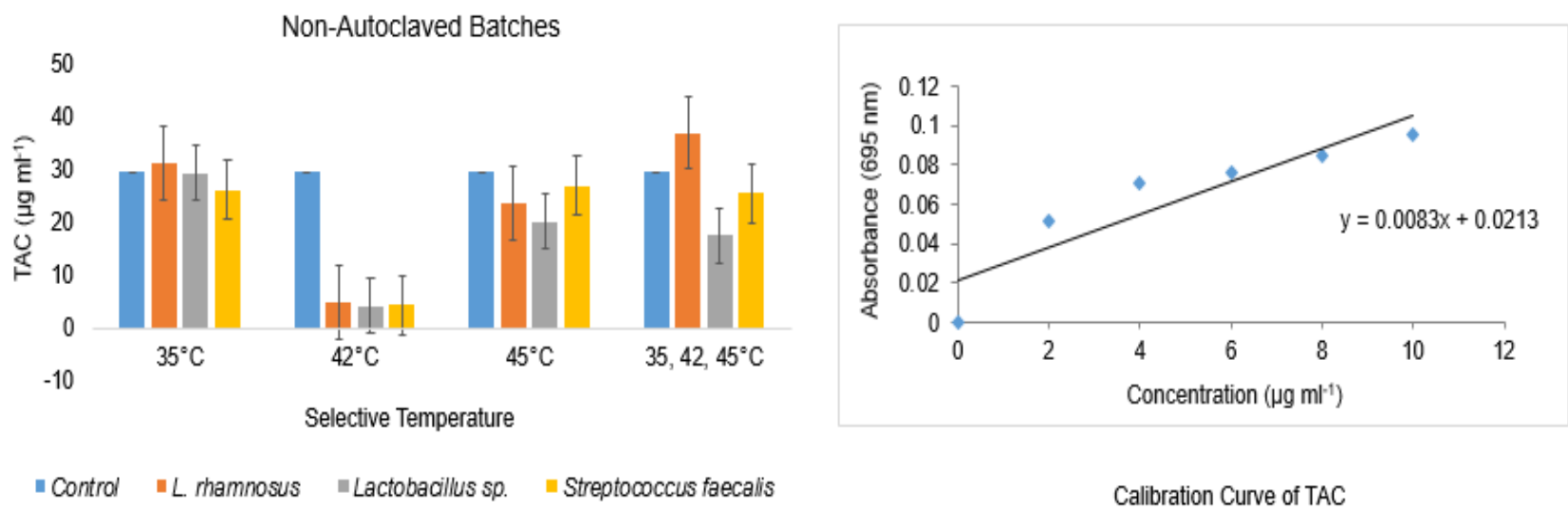

Fig. 3. TAC ( $\left.\mu \mathrm{g} \mathrm{ml}^{-1}\right)$ of pearl millet based probiotic fortified rabadi beverage fermented (non-autoclaved batch) at selective temperature

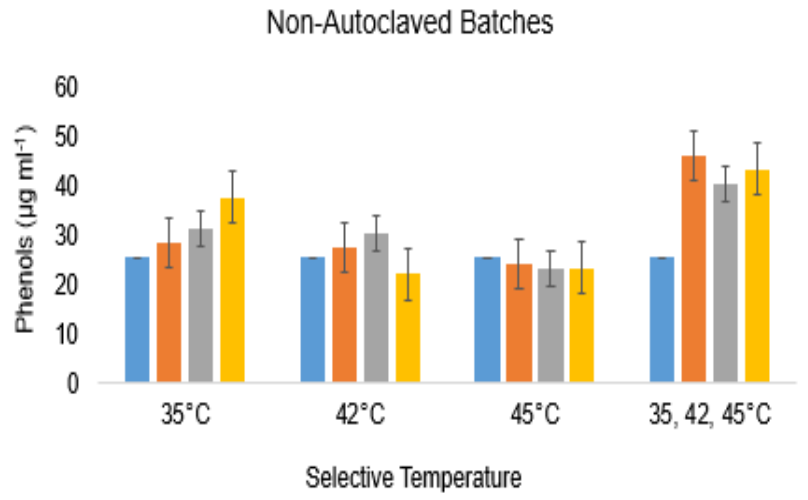

- Control $\|$ L. rhamnosus $\|$ Lactobacillus $s p . \quad \|$ Streptococcus faecalis

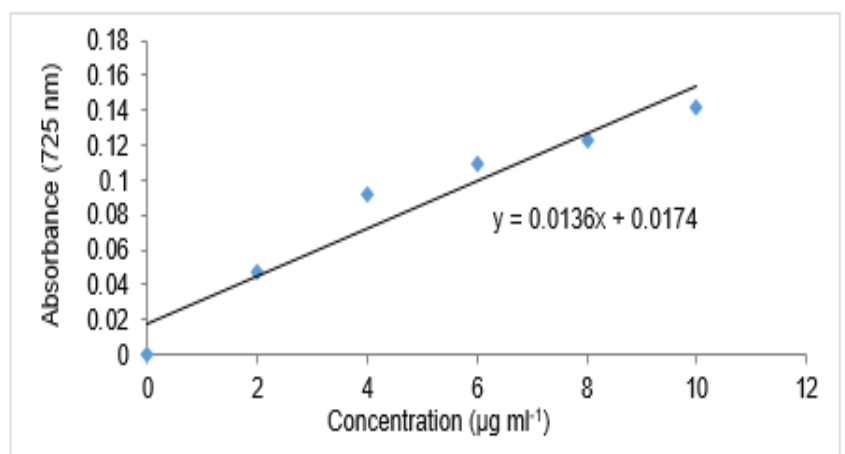

Calibration Curve of Phenols

Fig. 4. Phenols $\left(\mu \mathrm{g} \mathrm{ml}^{-1}\right.$ ) of pearl millet based probiotic fortified rabadi beverage fermented (non-autoclaved batch) at selective temperature

venting the bio-accessibility of nutrients. However, several studies have reported that these phenolic contents have health enhancing characteristics, including reducing heart disease and the inhibition of additional degenerative diseases (Dhankher and Chauhan 1987; Nambiar et al., 2011; Taylor and Duodu, 2015).

As depicted in Fig. 4 and 5, L. rhamnosus fortified rabadi beverage at $35,42,45^{\circ} \mathrm{C}$ of non-autoclaved batch showed significantly high content of TPC $(46.1 \pm 8.28$ $\left.\mu \mathrm{g} \mathrm{mL}^{-1}\right)$ and TFC $\left(29.91 \pm 7.73 \mu \mathrm{g} \mathrm{Ml}^{-1}\right)$ as compared to control $\left(25.53 \pm 5.75 \mu \mathrm{g} \mathrm{mL}{ }^{-1}\right.$ and $21.91 \pm 5.95 \mu \mathrm{g}$ $\mathrm{mL}^{-1}$, respectively) and other batches of Lactobacillus sp. and $S$. faecalis fortified rabadi beverage (Table 5). A similar report by Banwo et al. (2021a) showed the fermentation of millet and sorghum fortified with $L$. fermentum KL4, Lb. plantarum MOBL1, Candida tropicalis OBY6, and C. tropicalis MKY resulted in enhancement of total phenolics and flavonoid in the experimental outcome. The obtained outcomes agreed with the results reported by Salar et al. (2012). They showed that the solid-state fermentation increased the total phenolic content (free phenol) and antioxidant potential of corn to the growth rates of $20.05 \%$ and $36.73 \%$, respectively. Dlamini et al. (2007) also reported that the submerged fermentation also ensured significant results on the total phenolic content (free phenol) and antioxidant potential of sorghum (sludge and gruel).

Taylor and Duodu (2015) reported that these enhanced values were undoubtedly due to the discharge of bound phenol content from the millet's cell walls throughout the experimental procedure, which subsequently led to enhanced clearance of phenolic content. The mechanism of action for fermentation promotes the bioavailability of phenols in cereal grains. Matrix of cell wall has broken due to degrading enzymes in both microbes and grains and enhance the availability of bound and conjugated phenolics to enzymatic hydrolysis reaction (Akinola et al., 2017; Obadina et al., 2017; Aryal et al., 2019). During millets' fermentation processes, the synthesis or enzymatic modification of several bioactive components occurred, as evident in the study of Banwo et al. (2021b).

As depicted in Fig. 6, L. rhamnosus fortified rabadi beverage at $35,42,45{ }^{\circ} \mathrm{C}$ of non-autoclaved batch 

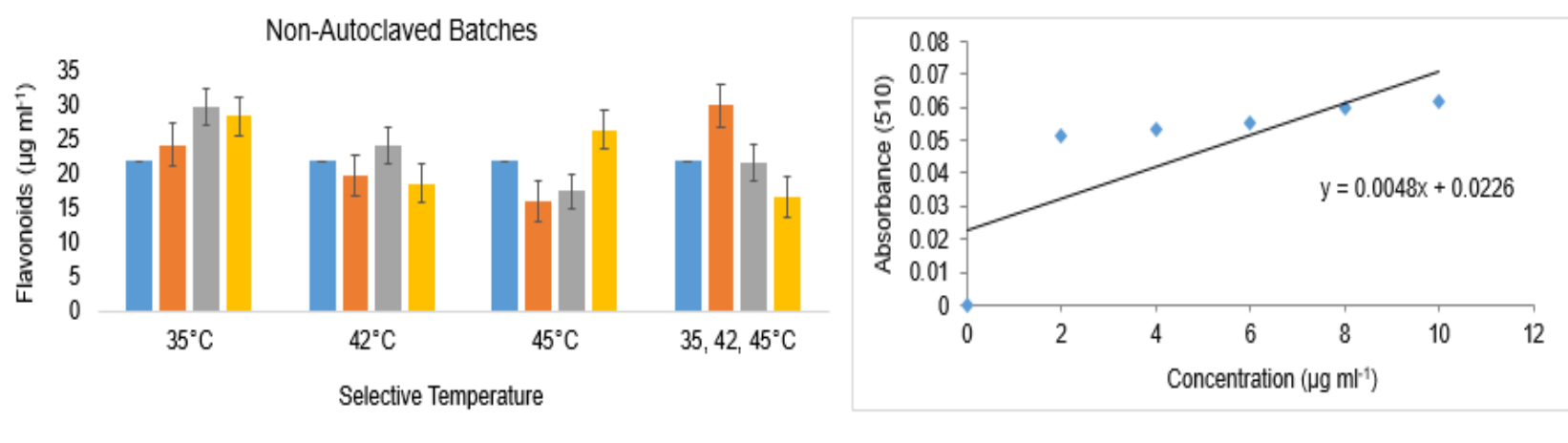

Control $\quad$ L. rhamnosus $\quad$ Lactobacillus sp. $\quad$ Streptococcus faecalis

Calibration Curve of Flavonoids

Fig. 5. Flavonoids ( $\mu \mathrm{g} \mathrm{ml}^{-1}$ ) of pearl millet based probiotic fortified rabadi beverage fermented (non-autoclaved batch) at selective temperature
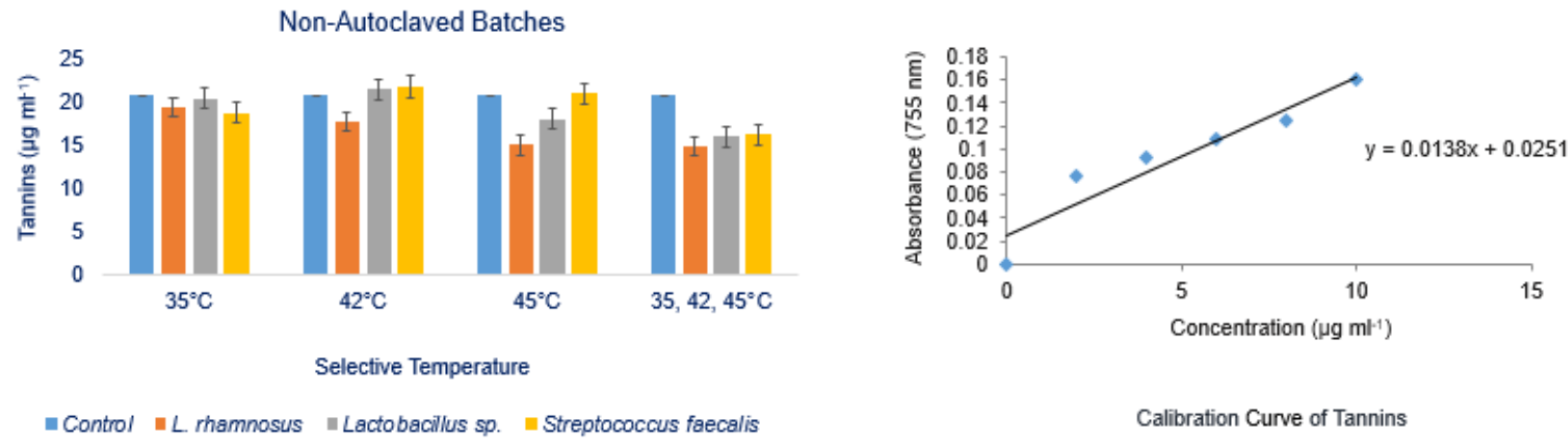

Fig. 6. Tannins $\left(\mu \mathrm{g} \mathrm{m}^{-1}\right)$ of pearl millet based probiotic fortified rabadi beverage fermented (non-autoclaved batch) at selective temperature

showed less tannins content $\left(14.84 \pm 4.64 \mu \mathrm{g} \mathrm{mL}^{-1}\right)$ as compared to control, i.e., $20.74 \pm 3.43 \mu \mathrm{g} \mathrm{mL}-1$. Agboola and Ojo (2018) reported that the reducing tannic acid content $(42.00 \mathrm{mg} / \mathrm{kg}$ to $24.03 \mathrm{mg} / \mathrm{kg}$ ) during fermentation with Saccharomyces cerevisiae and $L$. plantarum increases the mineral composition of millet-based fermented foods. Similarly, Srivastava et al. (2021) reported that during fermentation, reduction of the tannins present in the barnyard millet was measured from 2.07-0.006 $\mathrm{mg}$, in the range of tannic acid equivalent per gram. The bond that has been made between tannins and cotyledon endosperm is the issue for decrement of tannins content, which is unusual through the regular method because of the insolubility of tannins in the solvent or action of bacterial phenoloxidase.

\section{Conclusion}

The In silico study has proven the tremendous therapeutic potential of tannic acid and ascorbic acid in pearl millet. The study demonstrated that tannic acid and ascorbic acid were good antioxidants because they had interaction of such human protein that plays a key role in natural killer cell-mediated cytotoxicity, osteoclast differentiation, responsible to prion diseases, and platelet activation. In various high-level research, the chemical protein interaction has been widely used for biochemical reactions, enzyme nomenclature, diseaserelated network variations, human diseases, and drugs. L. rhamnosus fortified pearl millet-based rabadi beverage (non-autoclaved batch) through controlled fermentation showed the functional therapeutic potentials for developing functional food.

\section{ACKNOWLEDGEMENTS}

The authors duly acknowledge the financial assistance to Mr. Prakash Yadav from UGC, New Delhi, in the form of Junior Research Fellowship (JRF).

\section{Conflict of interest}

The authors declare that they have no conflict of interest.

\section{REFERENCES}

1. Agrawal, H., Joshi, R. \& Gupta, M. (2016). Isolation, purification and characterization of antioxidative peptide of pearl millet (Pennisetum glaucum) protein hydrolysate. 
Yadav, P. et al. / J. Appl. \& Nat. Sci. 13(4), 1531 - 1544 (2021)

Food Chem, 204,365-372. https://doi.org/10.1016/ j.foodchem.2016.02.127.

2. Agboola, S. A. \& Ojo, O. C. (2018). Effect of Lactobacillus Species and Saccharomyces cerevisiae on the mineral and anti-nutrient composition of Kunu-A fermented millet based food. Asian Food Science Journal, 1-8. https:// doi.org/10.9734/AFSJ/2018/44023.

3. Akinola, S. A., Badejo, A. A., Osundahunsi, O. F. \& Edema, M. O. (2017). Effect of pre-processing techniques on pearl millet flour and changes in technological properties. Int. J. Food Sci. Technol., 52,992-999. doi:10.1111/ ijfs. 13363.

4. Alard, J., Peucelle, V., Boutillier, D., Breton, J., Kuylle, S., Pot, B., Holowacz, S. \& Grangette, C. (2018). New probiotic strains for inflammatory bowel disease management identified by combining in vitro and in vivo approaches. Beneficial Microbes, 9(2),317-331. https:// doi.org/10.3920/BM20 17.0 097

5. Aryal, S., Baniya, M. K., Danekhu, K., Kunwar, P., Gurung, R., \& Koirala, N. (2019). Total phenolic content, flavonoid content and antioxidant potential of wild vegetables from Western Nepal. Plants, 8(4),96. doi:10.3390/ plants8040096.

6. Banwo, K., Asogwa, F. C., Ogunremi, O. R., AdesuluDahunsi, A., \& Sanni, A. (2021a). Nutritional profile and antioxidant capacities of fermented millet and sorghum gruels using lactic acid bacteria and yeasts. Food Biotechnology, 35(3), 199-220. https://doi.org/10.1080/0890 5436.2021.1940197.

7. Banwo, K., Fasuyi, T. O., \& Olojede, A. O. (2021b). Potentials of Lactobacillus plantarum and Pichia kudriavzevii in co-fermentation of sourdough from millet. International Journal of Food Science \& Technology, 56(2),857-864. doi:10.1111/ijfs.14729.

8. Callcott, E. T., Santhakumar, A. B., Luo, J., \& Blanchard, C. L. (2018). Therapeutic potential of rice-derived polyphenols on obesity-related oxidative stress and inflammation. Journal of Applied Biomedicine, 16(4),255-262. https://doi.org/10.1016/j.jab.2018.03.001.

9. Chandrasekara, A., \& Shahidi, F. (2012). Bioaccessibility and antioxidant potential of millet grain phenolics as affected by simulated in vitro digestion and microbial fermentation. Journal of Functional Foods, 4(1),226-237. doi:10.1016/j.jff.2011.11.001.

10. Chang, C. C., Yang, M. H., Wen, H. M., \& Chern, J. C. (2002). Estimation of total flavonoid content in propolis by two complementary colorimetric methods. Journal of food and drug analysis, 10(3). https://doi.org/10.38212/22246614.2748.

11. Cuevas, A., Saavedra, N., Salazar, L. A., \& Abdalla, D. S. (2013). Modulation of immune function by polyphenols: possible contribution of epigenetic factors. Nutrients, 5 (7),2314-2332. https://doi.org/10.3390/nu5072314.

12. Dhankher, N., \& Chauhan, B. M. (1987). Effect of temperature and fermentation time on phytic acid and polyphenol content of rabadi-a fermented pearl millet food. Journal of Food Science, 52(3),828-829. https://doi.org/10.1111/ j.1365-2621.1987.tb06739.x

13. Dlamini, N. R., Taylor, J. R., \& Rooney, L. W. (2007). The effect of sorghum type and processing on the antioxidant properties of African sorghum-based foods. Food Chemis- try, 105(4), 1412-1419. https://doi.org/10.1016/j.foodch em.2007.05.017.

14. Falcinelli, B., Calzuola, I., Gigliarelli, L., Torricelli, R., Polegri, L., Vizioli, V., Benincasa, P. \& Marsili, V. (2018). Phenolic content and antioxidant activity of wholegrain breads from modern and old wheat (Triticum aestivum L.) cultivars and ancestors enriched with wheat sprout powder. Italian Journal of Agronomy, 13(4),297-302. https:// doi. org/10.4081/ija.2018.1220.

15. Hager, C. L., \& Ghannoum, M. A. (2017). The mycobiome: role in health and disease, and as a potential probiotic target in gastrointestinal disease. Digestive and Liver Disease, 49(11),1171-1176. https://doi.org/10.1016/j.dld.201 7.08.025.

16. Hill, C., Guarner, F., Reid, G., Gibson, G. R., Merenstein, D. J., Pot, B. and Sanders, M. E. (2014). Expert consensus document. The international scientific association for probiotics and prebiotics consensus statement on the scope and appropriate use of the term probiotic. Nature Reviews Gastroenterology and Hepatology, 11,506-514. http://www.nature.com/doifinder/10.1038/nrgastro.20 14.66 .

17. Howell, D. C. (2012). Statistical methods for psychology. Cengage Learning.

18. Kerman, D. H., \& Deshpande, A. R. (2014). Gut microbiota and inflammatory bowel disease: The role of antibiotics in disease management. Postgraduate Medicine, 126,7-9. https://doi.org/10.3810/pgm.2014.07.2779.

19. Krishnan, R. and Meera, M.S. (2018). Pearl millet minerals: effect of processing on bioaccessibility. J Food Sci Technol, 55,3362-3372. https://doi.org/10.1007/s13197018-3305-9.

20. Liu, S., You, L., Zhao, Y., \& Chang, X. (2018). Wild lonicera caerulea berry polyphenol extract reduces cholesterol accumulation and enhances antioxidant capacity in vitro and in vivo. Food Research International, 107,73-83. https://doi.org/10.1016/j.foodres.2018.02.016.

21. Longvah, T., Ananthan, R., Bhaskarachary, K. \& Venkaiah, K. (2017). Indian Food Composition Tables. National Institute of Nutrition (ICMR), Department of Health Research, ministry of health \& Family Welfare, Government of India, Hyderabad, Telangana State, INDIA..

22. Menezes, A. G. T., Ramos, C. L., Dias, D. R. \& Schwan, R. F. (2018). Combination of probiotic yeast and lactic acid bacteria as starter culture to produce maize-based beverages. Food Res. Int, 111,187-197. doi:10.1016/ j.foodres.2018.04.065.

23. Nambiar, V. S., Dhaduk, J. J., Sareen, N., Shahu, T., \& Desai, R. (2011). Potential functional implications of pearl millet (Pennisetum glaucum) in health disease. Journal of Applied Pharmaceutical Science, 1(10), 62-67.

24. Ng, K. R., Lyu, X., Mark, R. \& Chen, W. N. (2019). Antimicrobial and antioxidant activities of phenolic metabolites from flavonoid-producing yeast: potential as natural food preservatives. Food Chemistry, 270,123-129. https:// doi.org/10.1016/j.foodchem.2018.07.077.

25. Noratto, G., Porter, W., Byrne, D. \& Cisneros-Zevallos, L. (2009). Identifying peach and plum polyphenols with chemopreventive potential against estrogen-independent breast cancer cells. Journal of Agricultural and Food Chemistry, 57(2),5119-5126. https://doi.org/10.1021/jf900 $259 \mathrm{~m}$. 
26. Nwinuka, N.M., Ibeh, G.O. \& Ekeke, G.I. (2005). Proximate composition and levels of some toxicants in four commonly consumed spices. J. Appl. Sci. Environ. Manag, 9, 150-155. http://hdl.handle.net/1807/6437.

27. Obadina, A. O., Arogbokun, C. A., Soares, A. O., Cwp, D. C., Barboza, H. T. \& Adekoya. I. O. (2017). Changes in nutritional and physico-chemical properties of pearl millet (Pennisetum glaucum) ex-borno variety flour as a result of malting. J Food Sci Technol, 54:4442-4451. doi:10.1007/ s13197-017-2922-Z

28. Ogodo, A., Agwaranze, D. I., Aliba, N. V., Kalu, A. C., \& Nwaneri, C. B. (2018). Fermentation by lactic acid bacteria consortium and its effect on anti-nutritional factors in maize flour. Journal of Biological Science, 19(1),17-23. https://doi.org/10.3923/jbs.2019.17.23.

29. Ogunremi, O. R., Agrawal, R., \& Sanni, A. I. (2015). Development of cereal $\square$ based functional food using cereal $\square$ mix substrate fermented with probiotic strain-Pichia kudriavzevii OG 32. Food science \& nutrition, 3(6),486494. https://doi.org/10.1002/fsn3.239.

30. Okoroafor, I., Banwo, K., Olanbiwoninu, A. \& Odunfa, S. A. (2019). Folate enrichment of Ogi (a Fermented Cereal Gruel) using folate producing starter cultures. Adv. Microbiol, 9,177-193. doi:10.4236/aim.2019.93014.

31. Olojede, O. A., Sanni, A. I. \& Banwo. K. (2020). Effect of legume addition on the physiochemical and organoleptic attributes of sorghum-based sourdough bread. LWT Food Sci. Technol., 118,108769. doi:10.1016/j.Iwt.2019.108769.

32. Pe`sic, M. B., Milin ' ci ` c, D.D. \& Kosti ` c, A. Z. (2019). In vitro digestion of meat- and cereal-based food matrix enriched with grape extracts: how are polyphenol composition, bioaccessibility and antioxidant activity affected?, Food Chemistry, 284, 28-44. https://doi.org/10.1016/ j.foodchem.2019.01.107.

33. Prieto, P., Pineda, M. \& Aguilar, M. (1999). Spectrophotometric quantitation of antioxidant capacity through the formation of a phosphomolybdenum complex: specific application to the determination of vitamin E. Anal Biochem., 269,337-341. https://doi.org/10.1006/abio.199 9.40 19.

34. Qian, Z. J., Jung, W. K., Kang, K. H., Ryu, B., Kim, S. K. and Je, J. Y. (2012). In vitro antioxidant activities of the fermented marine microalga Pavlova lutheri (haptophyta) with the yeast Hansenula polymorpha. J. Phycol., 48,475482. doi:10.1111/j.1529-8817.2012.01117.

35. Rani, S., Singh, R. \& Sehrawat, R. (2018). Pearl millet processing: a review. Nutr Food Sci, 48,30-44.

36. Reid, G. (2017). Probiotic use in an infectious disease setting. Expert Review of Anti-infective Therapy, 15, 449-
455. https://doi.org/10.1080/14787210.2017.1300061.

37. Salar, R. K., Certik, M. \& Brezova, V. (2012). Modulation of phenolic content and antioxidant activity of maize by solid state fermentation with Amnidium elegans CCF 1456. Biotechnology and Bioprocess Engineering, 17 (1),109-116, 2012.

38. Sharma, A., \& Kapoor. (1996). Effect of various types of fermentation on in vitro protein and starch digestibility of differently processed pearl millet. Food/Nahrung, 40(3), 142-145. https://doi.org/10.1002/food.19960400309.

39. Sidari, R., Martorana, A., Zappia, C., Mincione, A. \& Giuffrè,A. M. (2020). Persistence and effect of a multistrain starter culture on antioxidant and rheological properties of novel wheat sourdoughs and bread. Foods, 9 (9),1-24. https://doi.org/10.3390/foods9091258.

40. Singleton, V.L., \& Rossi, J.A. (1965). Colorimetry of total phenolics with phosphomolybdicphospho-tungstic acid reagents. American Journal of Enology and Viticulture, 16,144-158.

41. Srivastava, U., Saini, P., Singh, A., Singh, Z., Ahmed, M. \& Iqbal, U. (2021). Enhancement in iron and folate by optimizing fermentation of barnyard millet by Lactobacillus plantarum using response surface methodology (rsm). Plant Archives , 21(1), 993-1005.

42. Taylor, J. R. N., \& Duodu, K. G. (2015). Effects of processing sorghum and millets on their phenolic phytochemicals and the implications of this to the health-enhancing properties of sorghum and millet food and beverage products. Journal of the Science of Food and Agriculture, 95,225-227. https://doi.org/10.1002/jsfa.6713.

43. Vitale, M., Vaccaro, O. \& Masulli, M. (2017). Polyphenol intake and cardiovascular risk factors in a population with type 2 diabetes: the TOSCA.IT study. Clinical Nutrition, 36 (6),1686-1692. https://doi.org/10.1016/j.clnu.2016.11.002.

44. Xiao, J., Kai, G., Yamamoto, K. \& Chen, X. (2013). Advance in dietary polyphenols as $\alpha$-glucosidases inhibitors: a review on structure-activity relationship aspect. Critical Reviews in Food Science and Nutrition, 53(8),818-836. https://doi.org/10.1080/10408398.2011.561379.

45. Yépez, A., Russo, P., Spano, G., Khomenko, I., Biasioli, F., Capozzi, V. \& Aznar, R. (2019). In situ riboflavin fortification of different kefir-like cereal-based beverages using selected Andean LAB strains. Food Microbiol, 77,61-68. doi:10.1016/J.FM.2018.08.008

46. Zuo, Y., Chen, H., \& Deng, Y. (2002). Simultaneous determination of catechins, caffeine and gallic acids in green, Oolong, black and pu-erh teas using HPLC with a photodiode array detector. Journal of Talanta, 57,307-316. https://doi.org/10.1016/S0039-9140(02)00030-9. 